\title{
The Historical Basis of Aceh Socio-Economics Development (1511-1904)
}

\section{Mehmet Özay}

\begin{abstract}
It is vital to see the connection between experiences in history and contemporary developments in almost all corners of the world. Regions which appear as leading powers in economic developments have historically had their own particular dynamics. In the event that the dynamics of the past uncover the true means to go forward, it will trigger the path of progress at an unexpected time, when similar conditions are met. Taking this condition into account with regard to Aceh, we see that Aceh has been a potential candidate for the newly emerging economic development centers in Southeast Asia after the disastrous event on $26^{\text {th }}$ December, 2004, pursuant to which the Memorandum of Understanding (MoU) in Helsinki was signed by the related sides on $15^{\text {th }}$ August, 2005. To assess and evaluate the possibilities and opportunities that open up before Aceh Province by virtue of the MoU, the tradition of economic developments in history should be revisited and evaluated. It might be assumed that the reflections from the past will certainly enlighten the future. This article suggests that the economic development of the Sultanate of Aceh Darussalam in the past might be a starting point for all parties in Aceh Province to deduce exactly how to deal with prevailing difficulties so as to commence economic progress in the region. It is considered that historical experiences are repetitive. The significance of Aceh was based on several diverse factors, primarily its state structure, economic activities, and geo-strategic position on the extreme northwest of Sumatra, that allowed it to be a part of the international sea trade between the east and the west between the $16^{\text {th }}$ and $19^{\text {th }}$ centuries. These characteristics propelled Aceh to become not only a prominent region, but also gain supremacy in global partnerships in the business of international trade. After the peace agreement celebrations, it is the need of the hour for all social and economic sectors in Aceh Province to trigger the potentiality of their region by looking at their flourishing past.
\end{abstract}

Keywords: Aceh Sultanate, Southeast Asia, Indian Ocean, trade business. 


\section{Les Fondements Historiques Du Développement Socio-Economique d'Aceh (1511-1904)}

\section{Résumé}

Il existe une relation remarquable entre le développement économique actuel des pays et des régions et leurs expériences vécues dans le passé. Dans ce contexte, on peut suggérer que cette relation pourrait être basée sur les dynamiques propres à ces pays. En effet, avec la découverte de ces dynamiques qui existait dans le passé, on peut prévoir que certaines régions d'aujourd'hui peuvent de nouveau occuper une place sur la scène mondiale si des conditions similaires existent encore. Dans cet article, nous étudions que l'Aceh - si elle s'accorde aux développements récents dans le monde- a une potentialité qui lui donne une place méritée surtout dans les stratégies de développement socio-économique de l'Asie du Sud-ouest. Pour comprendre à quoi ce potentiel correspond, il faudra analyser la structure de l'économie et les interactions économiques émergeant de l'existence politique de l'Ache plus particulièrement à partir du début de $16^{\text {ème }}$ jusqu'au début du $20^{\text {ème }}$ siècle. Nous pensons que, au cours des siècles, la tradition étatique du Sultanat d'Aceh - qui lui a permis d'être l'objet des relations commerciales internationales entre l'est et l'ouest - ses activités économiques et sa position géostratégique seront des références pour son avenir.

Mots-Clés : Sultanat d'Aceh, Asie du Sud-ouest, Océan Indien, Commerce International.

\section{Açe'deki Sosyo-Ekonomik Kalkınmanın Tarihsel Temelleri (1511-1904)}

\section{Özet}

Ülkelerin ve coğrafyaların bugünkü ekonomik gelişmişlikleri ile geçmişte yaşadıkları tecrübeler arasında dikkate değer bir ilişki vardır. Bu bağlamda, bu iliş̧kinin söz konusu bölgelerin kendine has dinamiklere dayandığı ileri sürülebilir. Öyle ki, geçmişte var olan bu dinamiklerin keşfiyle, bugün kimi bölgelerin, benzer koşulların hasıl olması halinde, yeniden dünya sahnesinde varlık bulabileceklerini öngörebiliriz. Bu makalede, Açe'nin, son dönemde yaşanan gelişmeler 1şı̆̆ında ele alındığında, dünyanın özellikle de Güneydoğu Asya'nın sosyo-ekonomik kalkınma stratejileri içerisinde hak ettiği yeri alabilecek bir potansiyele sahip olduğu üzerinde durulmaktadır. Bu potansiyelin nelere tekabül ettiği, Açe'nin özellikle 16. yüzyıl başlarından 20. yüzyıl başlarına kadar devam 
eden siyasi varlığı içerisinde ortaya çıkan ekonomik yapısı ve ekonomik etkileşimlerinin analiz edilmesiyle yakından ilintilidir. Açe İslam Sultanlığı'nı sözü edilen yüzyıllar içerisinde, Doğu-Batı arasındaki uluslararası ticaret ilişkilerine konu olmasını sağlayan devlet geleneği, ekonomik aktiviteleri ve jeo-stratejik konumunun Açe'nin geleceği için bir referans olacağını düşünüyoruz.

Anahtar Kelimeler: Açe Sultanlığı, Güneydoğu Asya, Hint Okyanusu, uluslararası ticaret.

\section{الأساس التاريخي للتنمية الاجتماعية والاقتصادية في اتشيه (1904-1511)}

$$
\begin{aligned}
& \text { ملخص } \\
& \text { لا شك أن هناك علاقة وثيقة بين بحارب الدول والمناطق المختلفة في الماضي وبين الحالة الإقتصادية التي } \\
& \text { تعيشها تلك الدول والمناطق اليوم. هذه العلاقة التي كانت موجودة في الماضي والتي نشأت على أساس عوامل وظروف } \\
& \text { خاصة بتلك الدول والمناطق، يمكن اكتشافها مرة أخرى اليوم وتطويرها على الساحة العالمية في بعض المناطق الأخرى } \\
& \text { من العالم لظروف مشابهة. وهذا البحث محاولة لتحليل واقع مدينة اتشيه، وبيان الاستراتيجيات المطلوبة لما في ضوء } \\
& \text { التغيرات السياسية والاقتصادية التي يمر بها العالم وخاصة جنوب شرق آسيا في الآونة الأخيرة من جانب. ومن جانب } \\
& \text { آخر محاولة اكتشاف مدى وجود العلاقة بين ما كانت تملك من إمكانات واستراتيجيات سياسية واقتصادية هائلة في } \\
& \text { الماضي، خاصة في القرن السادس عشر وبداية القرن العشرين الميلادي، وحالتها السياسية والإقتصادية اليوم. وأخيرا } \\
& \text { نعتقد أن سلطنة اتشيه بما لها من تاريخ عريق وموقع جغرافي استراتيجي خاصة في بحال التجارة الدولية والربط بين } \\
& \text { الشرق والغرب مؤهلة لمستقبل أفضل. } \\
& \text { كلمات البحث: سلطنة اتشيه، وجنوب شرق آسيا، والأعمال التجارية }
\end{aligned}
$$




\section{Introduction}

This article aims to offer an intimate insight into the significance of the Aceh region and some background on the economic activities during the lifetime of the Sultanate of Aceh Darussalam (SAD) (1511-1904). Basically, as regards the establishment of the new power structure of the Aceh Sultanate, two characteristics are worthy of attention. These are the geostrategic position and the economic potentiality of the region. However, though these tangible factors are significant enough, they do not mean much without a consideration of the human factor, and hence attention should be given to the native people and their characteristics as well. As focused on in detail below, the text emphasizes some salient aspects of the socio-economic development of Aceh in history that could have an influence on the improvements in Aceh Province today. These aspects may be categorized as follows: a) political determination of charismatic and democratic leadership; b) economic productivity, particularly based on the characteristic agricultural productivity of the region; c) being a part of international trade interactions; d) social peace among distinct and diverse ethnicities; e) cosmopolitan city settlements; f) being involved as an active participant in global sea trade; and f) Islamic thought and leadership in Southeast Asia (SEA). Nevertheless, due to shortage of space, we cannot deal with all these aspects, and instead will focus on just a few. It appears that all these aspects had some level of impact on the development of the SAD throughout history. Thus, all these characteristics allowed Aceh to exist throughout and until the end of the $19^{\text {th }}$ century. As emphasized by Anthony Reid, despite some of its weaknesses, Aceh overall succeeded in continuing its sovereignty.[1]

Nevertheless, anthropologically we cannot talk about any geo-strategic and economic factors without taking into consideration the characteristics of human beings. Though our aim in this preliminary article is not to deal with the current issue anthropologically, it should be emphasized that the aforementioned categories, at least some of them, help us discover who the Acehnese were. We will also briefly focus on the politico-philosophical attitude of the rulers of Aceh. The founding of Aceh was the result of the determined religio-political thought of the native rulers. Though the establishment of Aceh was in line with the fear of "the Portuguese terror spreading everywhere", particularly in the Malacca city-state, the new state's coming into being in the region had its own parameters and reasons. Thus, without the religio-political determination mentioned earlier, it is difficult to understand both the identity of the Acehnese and the continuity of the Aceh Sultanate.[2] This approach finds support in the ideas expounded by various scholars of Aceh history. For instance, Horace John has a unique viewpoint on Aceh and the Acehnese. On the one hand he emphasizes that Aceh as a region was very productive and had 
many types of agricultural produce, and on the other hand he defines the Acehnese as more industrious and intelligent compared with other regional natives.[3]

Though the influence of the Portuguese, who were aiming to create a monopoly in trade by virtue of its military power in the Indian Ocean and SEA, was a fact, this western colonial power's involvement in the region provoked a triggering effect on the progressive development of the SAD. In this context, the Aceh Sultanate was to become a global player in various aspects which will be dealt with later. However, admittedly, the importance of Aceh will only be estimated appropriately if the crucial role that the Indian Ocean played in the development of Mediterranean society and economy is kept in mind.[4]

Since the concept of a federation of petty city-states among the societies in the region was itself a novel and pioneering ideology in the political arena, the new structure of the state power of Aceh must be regarded as the initial phase of a modern era in SEA. This is also defined as the "age of commerce" by Anthony Reid. During this era, according to Reid, "a few port-states developed enough internal power as novel 'gunpowder empires' to give rise to new ethnicities. ... Aceh at $17^{\text {th }}$ century apogee were strong enough to develop some state nationalism based on military mobilisation, dynastic pride and Islam." [5]

In addition to the quotation above, trade and Islam were two relevant and inevitable phenomena of Aceh history.[6] Generally, in line with most religions introduced particularly in the port-cities of SEA on the sea-trade route, Islam too played a significant role in the region. And since merchants were the catalysts of religious ideology, it must be said that there was an interrelation between trade and religion in Aceh's development in history. This issue was highlighted throughout the struggle with the Portuguese and then the Dutch.[7] For instance, as the center of the development of Islamic culture and civilization in SEA, Aceh aimed to have an enduring relationship with the center of Islam, the Holy Land. Acehnese rulers determinedly formulated attempts to integrate Islamic societies around the Malacca Strait. On the other hand, being a constructive power of the global mercantile community, Aceh extended its relations in longue durée till the Middle East and Nusantara in the east.

\section{Political Determination: Beginning of the 16th Century and Aceh as an Emerging}

\section{Power}

As far as regional, political, and economic aspects were concerned,[8] the Sultanate of Aceh Darussalam was regarded as the natural inheritor of the Samudra-Pasai Sultanate (1250-1524).[9] By the focal position that it occupied in the power relations of the region, Aceh united all Sumatranese city-states such as Lambryi (Biar Lambry), Pedir, Pirada, Pasae, Bata, Aru, Arcat, 
Rupat, Siak, Campar, Tuncall, Indragiri, Capocam, Trimtall, Jambi, and Palembang, some of which were Islamic sultanates.[10] On account of this success, based on the determination of its rulers to have territorial sovereignty, be actively involved in the international trade between east and west, and challenge the Western colonial powers in the region, Aceh Darussalam was rightly defined as a sea empire.[11] Aceh, on the one hand, being a pioneering navy power against the Portuguese, established a strong military, and on the other hand, with its trade relations and spice trade with the Middle East, increased the income of the state budget.[12]

After Malacca was captured by the Portuguese who were challenging the regional powers for both religious and economic reasons, Aceh emerged as a leading power on the northern tip of Sumatra Island. The Portuguese reconquista ideology, imported from the Iberian Peninsula in southwestern Europe, forced Muslim traders and seamen from Malacca to take refuge around the Aceh region. Also, the Portuguese, desirous of being the sole economic power in Malacca, caused non-Muslim traders from various religious backgrounds and regions such as Coromandel, Ceylon (Sri Lanka), Bengal and Pegu (Burma) to settle in Aceh port-cities especially Bandar Aceh.[13] Thus the power equations in and around the Malacca Strait had a direct impact on the northern tip of Sumatra Island. That Ali Mughayat Syah, the founder of the state, was able to establish and expand the borders of Aceh proved that he had the distinguished political traits of a statesman. Prudently taking the tradesmen and heads of states into consideration and confidence, Aceh was able to manouvre through the complex equations in the region, thus allowing the Acehnese to be abreast of the developments of Portuguese activities in the Indian Ocean. This is possibly the reason why Ali Mughayat Syah decided to prepare for a federative political unity before the direct invasion of the Portuguese in north Sumatra. This predictive political acumen led Aceh to become a strong sea power in the next developmental phases of the region.

The prevailing political environment was not an obstacle for the distinct power holders. Instead, they coexisted in a harmony based on their socio-cultural understanding of the circumstances of the time. As the saying goes in economics, 'money loves peace'. The federated political structure allowed the commercial actors in Aceh to expand their economic development and existence as far as Western India, Southern Arabia and the Middle East in the western part of the Indian Ocean, in the Bay of Bengal and Malaya in SEA, and in Western Java and China in the east.[14] It depicts an idyllic picture of political, social, and economic cooperation, and emphasizes the astuteness and superiority of the Aceh Sultanate. It must be admitted that what kept the development of Aceh alive and vibrant until a very late period, with occasional exceptions, was the determination of Acehnese statesmen. The realm reached its zenith around the middle of the $16^{\text {th }}$ century in the era of Iskandar Muda (1607-1636) which is known as the most prosperous in all Aceh history. Even though it gradually lost much of its power, the Aceh 
region was one of the last bastions that remained uninfluenced by the Dutch, and this facet assumes crucial importance when its relationship with the Holy Land of Islam, say Makkah, is taken into consideration.[15]

Some Reflections from the Past to Today: Socio-Economic Development of the Aceh Sultanate

When Aceh became a dominant state power of SEA, its political, economic, and religious parameters were regarded as integrated in various degrees. Politically, its rulers created charismatic leadership models; economically, Aceh was the main center of production for precious spices such as pepper, clove, nutmeg, and an entrepot "along the Muslim route to the Red Sea, Egypt and the Mediterranean" [16]; in the religious context, visitations of religious scholars from various Islamic centers and contributions of local ulema helped establish Aceh's own "teaching schools" as a part of Islamic civilization in SEA. In the international arena, Aceh opened a direct sea link, via the Western Indian Ocean, to Arabia, after the frequent attempts by the Portuguese, who dominated the Indian Ocean, to waylay pilgrims from SEA on their annual visit to Arabia to conduct the Haj ritual.[17]

The major income of the Aceh region, similar to the other regional port-city states, came from commercial activities in the Indian Ocean and some other related parts of Nusantara in the east. Since the state's income was based on regional and global trade businesses, the Acehnese rulers, creating a healthy economic milieu so as to allow the business of trade to continue to flourish, played a salient role in the development of the region.[18] In fact, the future of a potentate's political power was directly proportionate to his involvement in, and control of, mercantile activities. From a detailed reading of Aceh history, it appears that almost all rulers put in tremendous effort to deal directly with trade activities conducted both in the capital and in other port-cities along the border of the Sultanate. That the most successful in this enterprise automatically held power in the court illustrates the close relationship that existed between commercial practice, bureaucratic arrangements, political stability, and the future of the monarch, not only in the state but also in the international domain. It can therefore be said that the foundation of political power was relatively based on the control that a ruler exercised on the economic activity in port-cities.

Beyond that, the political and military powers were very determined in their efforts to establish economic relations with foreigners, going to great lengths to circumvent blockades and restrictions on their free passage through the ocean. As a unique example from the developing 
era of the Sultanate, during the reign of Alaaddin Riayat Shah al-Qahhar (1537-1568) in the 1550s, the Acehnese traders carved out their own travel route via the Maldive Islands, thus playing a significant role in the Middle East spice trade, while trying to outflank the ever present threat of the Portuguese in the Western Indian Ocean. To be able to understand and evaluate the role of Acehnese rulers and traders in the Western Indian Ocean at that time, we should keep in mind that the Middle East port cities supplied half of the total spice demand of Europe. This accomplishment alone made the first European trade charter companies obey the trade regulations established by the sultans themselves without any conditions or preconditions, from the end of the 16th century.[19]

We should dwell briefly here on the monetary policies of the Sultanate, which is a crucial aspect of governance. Monetary policies have always been very significant throughout history in all sizeable states and empires. In this context, Acehnese rulers proved both their state's and their own individual political power by minting various types of coins. For instance, gold coins were not only a prestigious feature of sultans in the Islamic world, but also an indication of economic sovereignty. Aceh had enough natural resources and gold mines in and around central Aceh and Minangkabau to mint their own gold coins. Renowned Samudra-Pasai gold coins continue to be discovered and excavated even today by native inhabitants in Samudra district, proving that from the very early ages the region had its own monetary regulation. In the Sultanate of Aceh Darussalam, as pointed out by some sources during the era of al-Kahhar, there were various types of monetary policies, including the minting of lead (keuh), silver, and gold (dirham).[20]

As mentioned earlier in this treatise, the human factor presides above all other aspects, sociologically. Economic and social life inevitably have a constant and strong relationship, when it comes to social peace and state regulations. With regard to this issue, Bandar Aceh, the capital city of the state, appeared a cosmopolitan city which was inhabited by various people of different social, cultural, religious, and economic backgrounds, coming from distant regions around the Indian Ocean. According to one source possibly of the year 1640, commercial activities would come to a halt for some time each year on account of climatic reasons, and trade vessels would spend some four months anchored at port, due to inclement weather. This factor led foreign merchants to settle in the port-cities.[21] Each ethnic group lived together in a certain part of the city and conducted its own business activities in various degrees. This presents a picture of global interaction, in which Aceh occupied the focal position in various spheres, economic, political, and religious. As stated in a book scripted by a traveller, there were traders from the western part of the ocean, from places such as Gujarat, Calicut, and the Island of Ceylon, to the eastern part, such as Siam, Bengal, and other places, well entrenched and conducting their trading activity while waiting for the next season to resume their travel.[22] The names of the various districts of 
Bandar Aceh, that endure to this day, bear eloquent testimony to this historical fact. Without the intention and social policies of the rulers, foreigners could not settle in the city. The sultans, however, with their penchant, inclination and commitment to international trade, created a climate conducive for foreign visitors. For instance, each foreign community had its own representative at the court to bespeak its collective social or economic legal cases, and each community had the right to follow its own legal counsel. Overseeing this organized mélange of people from diverse cultures and backgrounds was a sound bureaucracy under the direct supervision of a seasoned and respected bureaucrat, and, finally, the sultan himself. Socioeconomic life in Aceh was subject to similar regulations as those that were enforced in England, France and the Netherlands during the middle ages.[23]

Aceh, being located in the middle of the Indian Ocean, had, historically, a cosmopolitan cultural life and rich rural hinterland with an abundant supply of products and raw materials, and therefore was an attractive destination for foreign merchants and seamen from various areas. The cosmopolitan port-city of Bandar Aceh had an excellent infrastructure and amenities to facilitate the conduction of international trade. These characteristics collectively made Bandar Aceh a prominent port-city from the 1530s. This period witnessed trade activity between the Sultanate and Middle East ports such as Aden and Jeddah.[24] For instance, during the era of Iskandar Muda, there were annually around one hundred trade vessels anchored at Bandar Aceh port. The volume of merchandise on offer, and the security and safety provided by the Sultanate, were the principal factors that drew so many various types of vessels. Gold and lead coins were the medium of trade interactions, and it is also understood that this medium of trade continued in the 18th century.[25] As a matter of additional interest, it should be mentioned that the foreign exchange business was mainly in the hands of women in Bandar Aceh.[26]

\section{From Regional Relations to Global Ones}

The various produce and products of SEA or the Malay archipelago, since the beginning of the Roman Empire, were greatly sought after in the global markets of Europe. This demand gradually increased over the years in line with the social changes in the continent of Europe, such as an increase in population. The burgeoning demand during the years from 1500 to 1570 had a direct impact on the commercial output of the Aceh region, especially during the regency of Alaaddin Riayat Syah al-Qahhar, the third sultan.[27] As emphasized by renowned historian A. Reid, Acehnese merchants and vessels, trading with the port-cities in the West Indian Ocean, reached a significant level of importance with relation to the Middle East spice trade.[28] In addition, the Acehnese rulers were in close contact with the ancient seamen of Gujarati and Malabarese origin, so as to be able to send their cargoes of spice to the Middle East.[29] 
The Acehnese relations with the Middle East were commented and debated upon by various sources including the Ottomans, Portuguese, as well as the Acehnese. As part of this general global aspect of relationships, and in particular with regard to the Ottoman Empire, Aceh most importantly had international political involvement with the Middle East. As a result of this involvement there was a direct impact on the political and military power structure of the Sultanate. The details of this progress are provided by a letter sent by al-Qahhar to Sulayman I, the Magnificient (1522-1566), the $10^{\text {th }}$ Sultan of the Ottoman Empire. Titled "Letter from the Sultan of Aceh to Sultan Sulayman", it is preserved in the archive of Topkap1 Palace in Istanbul.[30] This letter should be regarded as an initial attempt to develop a pan-Islamist religiopolitical establishment. As a Portuguese source, Fernao Mentez Pinto, emphasized, some Ottoman statesmen reached Aceh via some four Acehnese spice cargo vessels from Jeddah around the second half of the 1530s.[31] Relations with the Turks were also emphasized in the classical Malay work Bustan'us Salatin. Based on the information gleaned from these manuscripts, al-Qahhar sent some envoys to Constantinople:

"Ialah yang mengadatkan segala istiadat kerajaan Aceh dan menyuruh utusan kepada sultan Rom, ke Negeri İstanbul karena meneguhkan agama Islam. ... Maka pada zaman sultan itulah dituang orang meriam yang besar-besar. Dan ialah yang pertama-tama berbuat kota negeri Aceh darussalam, dan ialah yang pertama perang dengan segala kafir, hingga sendirinya berangkat menyerang melaka[32]

What are the meanings of these quotations pertaining to the Acehnese and Ottomans? How should they be read and interpreted? At the first hand, the aforementioned letter was an intentional act of a resolute ruler to help close a much lamented gap between the central Islamic world and its periphery, in the beginning of the modern historical period of the Southeast Asian Islamic community. Al-Qahhar, as is evident from his title, was staunchly determined to conduct political and military activities in a regulated way. In addition, as witnessed by this letter, he was very aware of the contemporary power equations of the time and strove to improve the direct correspondence with the head of the Islamic world in Constantinople. Again, Al-Qahhar, as mistakely commented on by some Turkish historians, did not request or offer military help, but rather intended to keep open a dialog between the power center in western Asia and the chief representative of the growing leadership of the eastern Asian Islamic world, the Sultan of Aceh. In the letter he emphasized that he would not only pledge military help, but also offered to share the natural resources of Aceh in the contemporary international market by establishing a 
consensus with the Ottoman administration.[33] A similar comment, based on a misconstruction of the correspondence, can be found in a newly published work by Giancarlo Cassale who argued that the attempt of al-Qahhar was just intended for "commercial transaction, rather than any highminded political or military cooperation"[34]

The era of al-Mukammil (Alaaddin Riayat Syah IV, 1585-1604)[35] looked like what appeared to be a refurbishing of the Aceh administration system and international commercial activity in ports. Based on the observations of the Dutch, and British envoys and traders of charter companies during the reign of al-Mukammil, there was a port management system under the control of a syahbandar.[36] Aceh developed by leaps and bounds during the years between 1540 and 1570, and the era of Iskandar Muda is known as the golden era of the sultanate. Subsequently, even though political and military power gradually waned from about the middle of the $17^{\text {th }}$ century, Aceh continued its policy of international relations. Its decreasing power notwithstanding, its geo-strategic location predisposed some sultans towards continuing international politics with foreign powers. The Sultanate continued to maintain cordial relations with all contemporary power holders from the Middle East until the $19^{\text {th }}$ century, and this fact is bespoken by the number of foreign envoys from various states and regions who visited Aceh.[37]

The vast turnover of development and progress that began from the very early decades of the $16^{\text {th }}$ century lasted almost one hundred years until the middle of the $17^{\text {th }}$ century. Aceh became a leading and conspicuous power in the region, and was classified as one of the five most prominent Islamic states of that time.[38]

To date, although there is no evidence to point to any relationship between the Ottoman Empire and the Acehnese powers in the $18^{\text {th }}$ century, there was a notable connection between the two principalities during the developmental phase of the $16^{\text {th }}$ century. The socio-political connections with the Turkish side was kept alive particularly by the Acehnese pilgrimages to Mecca, and throve again from the middle of the $19^{\text {th }}$ century, in and around the time of the Dutch War in 1873.[39] It merits mention here that during the Crimean War (1854-56) between the Ottomans and the Russians, Sultan Ibrahim of Aceh contributed 10,000 Spanish dollars to the Ottoman war chest.[40]

\section{Acknowledgement}

The realization of this paper relatively in a short time is a product of convenient conditions which I always meet in the Faculty of Education, especially Assoc. Dr. Hamdan Said, the head of the Foundanitonal Education who creates conditions for me whenever I need to conduct my 
research. In additon, I would especially like to thank to the staff in the library of Sultanah Zanariah, UTM Skudai, where I always spend invaluable time.

\section{Conclusion}

The intent of this article is to encapsulate the various parameters concerning the Aceh Sultanate in history, so as to lead to the regeneration of fresh new policies in the region. It is known that the parameters of today are different from the ones in previous centuries. How Aceh might reach a satisfying level of socio-economic improvement, if not fully regain its past glory, is very crucial and admittedly open to debate. However, getting a historical perspective from a closer look at Aceh society, its leading figures and even common Acehnese as they were in the golden ages of the past, may well produce a clutch of constructive ideas to change the fate of its history.

Today we do not have much data relating to the various aspects of city life, the daily activities of the common people, or port and trade regulations in Aceh. However, its geopositional location might lead researchers to conduct a comparative study of the historical existence of the Aceh Sultanate with another respected western Indian port-city such as Aden, or Banten in eastern India. Since commercial activities were conducted between the western and eastern parts of the Indian Ocean by almost the same prototype of seaman and tradesman from the same region, prominent Indian Ocean merchants with complete control over shipping for example, they must have influenced each other in the introduction of customs regulations and bureaucracies. The data thus collected, compiled, and collated for concurrent port-cities of the time will yield information enough to reconstruct the conditions in Aceh some centuries ago, using the comparative approach.

It should be remembered that if today Malaysia, Singapore, and Thailand are the leading economic powers of Southeast Asian states, it is not merely through historical chance, but rather a proof of historical continuity. The Aceh Province might learn some constructive lessons from the historical facts of their land that could enable the reconstruction of their socio-economic development. This would be beneficial not only for Aceh province alone, but also for the region as a whole.

\section{REFERENCES}


[1]Anthony Reid, Imperial Alchemy: Nationalism and Political Identity in Southeast Asia, Cambridge University Press, Cambridge, 2010, p.116.

[2] Peter J. M. Nas, "The Early Indonesian Town: Rise and Decline of the City-State and Its Capital", In The Indonesian City, (eds.) Peter J. M. Nas, Foris Publications, Dordrecht-Holland, 1986, p. 32; Arun K. Dasgupta, Acheh in Indonesian Trade and Politics: 1600-1641, Cornell University, 1962, p. 35-6; B. Schrieke, Indonesian Sociological Studies, Part 2, W. Van Hoeve Ltd-The Hague and bandung, 1957, p. 235, 260.

[3] Horace St. John, The Indian Archipelago: Its History and Present State, Vol. I, Longman, London, 1853, p. 91-2.

[4] Roxani Eleni Margariti, Aden and The Indian Ocean Trade: 150 Years in the Life of a Medieval Arabian Port, The University of North Carolina Press, 2007, p. 19.

[5] Anthony Reid, 2010, p. 115.

[6] James T. Siegel, The Rope of God, University of California Press, Berkeley, 1969, s. 4; Lukman Thaib, The Roots of The Acehnese Struggle, 2000, p. 3; Anthony H. Johns, "Islam in Southeast Asia: Reflections and New Directions", In Indonesia, (eds.) (unknown name), Cornell University Press, Ithaca, New York, 1976, p. 38; Moshe Yegar, Islam and Islamic Institutions In British Malaya, The Magnes Press, The Hebrew University, Jerusalem, 1979, p. 7.

[7]Anthony Reid, "The Pre-modern Sultanate's View of Its Place in the World", In Verandah Of Violence -The Background to the Aceh Problem-, (eds.) Anthony Reid, Singapore University Press, 2006, p. 55.

[8]Teuku H. İbrahim Alfian, "Islam Dan Kerajaan Aceh Darussalam”, In Sejarah Dan Dialog Peradaban, (eds.) Taufik Abdullah, LIPI Press, Jakarta, 2006, p. 239.

[9]Ito Takeshi, The World of the Adat Aceh: A Historical Study of the Sultanate of Aceh, PhD Dissertation, Australian National University, 1984, p. 1, 58; Ali Hasjmy, Ruba'i Hamzah Fansuri -Karya Sastra Sufi Abad XVII-, Dewan Bahasa dan Pustaka, Kuala Lumpur, 1976, p. 1; Teuku H. İbrahim Alfian, 2006, p. 239.

[10]Armando Cortesao, (Ed.), The Suma Oriental Of Tome Pires, I. Cilt, Asian Educational Services, New Delhi, 1990, p. 135.

[11]Halil İnalc1k, "The Ottoman State: Economy and Society: 1300-1600, In An Economic and Social History of the Ottoman Empire: 1300-1914, (eds.) Halil İnalc1k; Donald Quataert, Cambridge University Press, Cambridge, 1994, p. 328. 
[12] D. G. E. Hall, A History of South-East Asia, Third Edition, The Macmillan Press Ltd., London, 1976, p. 218.

[13]M. C. Ricklefs, Sejarah Indonesia Modern 1200-2004, Serambi, 2004, p. 81; John Bastin; Robin W. Winks, (eds.) Malaysia: Selected Historical Readings, Nendeln, Liechetenstein, 1979, p. 61; V. K. Chavda, "Trade and Urbanization in Gujarat in the Early $17^{\text {th }}$ Century: A Dutch Account", In Precious Metals and Commerce, (eds.) Om Prakash, Variorum, 1994, p. 69; D. J. M. Tate, The Making of Modern South-East Asia, Vol. 1, Oxford University Press, Revised Edition, Kuala Lumpur, 1977, p. 223; ${ }^{1}$ John Bastin, "The Changing Balance of the Southeast Asian Pepper Trade", In Spices in the Indian Ocean World, (eds.) M. N. Pearson, Variorum, 1996, p. 293; B. Schrieke, 1957, p. 235.

[14]Anthony Reid, "Islamization and Christianization in Southeast Asia: The Critical Phase, 1550-1650”, In Southeast Asia in the Early Modern Era: Trade, Power and Belief, (eds.) Anthony Reid, Cornell University Press, Ithaca, 1993, p. 164; Lukman Thaib, 2000 , p. 3.

[15]C. R. Boxer, The Portuguese Seaborne Empire: 1415-1825; Carcanet, Lisbon, 1991, p. 43; Anthony Reid, "Indonesian Diplomacy A Documentary Study of Atjehnese Foreign Policy in the Reign of Sultan Mahmud: 1870-4”, JMBRAS, Vol. XLII, Part 2, December, (1969), p. 74.

[16]Anthony Reid, (eds.), Witnesses to Sumatra: A Travellers' Anthology, Oxford University Press, Kuala Lumpur, 1995, p. 54.

[17]Anthony Reid, "Introduction", (Ed.), Anthony Reid, The Making of An Islamic Political Discourse in Southeast Asia, Aristoc Press Pty, Centre of Southeast Asian Studies, Monash University, Clayton-Victoria, Australia, 1993, p. 7.

[18]K. N. Chaudhuri, "European Trade with India", In The Cambridge Economic History of Indian, (eds.) Tapan Raychaudhuri; Irfan Habib, Vol 1:1200-1750, Cambridge University Press, Cambridge, 1982, p. 384.

[19]B. Schrieke, 1957, p. 235; Anthony Reid, An Indonesian Frontier-Acehnese and Other Histories of Sumatra-, p. 6.

[20]Ali Hasjmy, 50 Tahun Aceh Membangun, Majelis Ulama Indonesia, 1· Bask1, Bali Medan, 1995, p. 135.

[21]Ito Takeshi, 1984, p. 276.

[22]François Martin, “Aceh in 1602”, In Witnesses to Sumatra: A Travellers' Anthology, (eds.) Anthony Reid, Oxford University Press, Kuala Lumpur, 1995, p. 63.

[23]D. G. E. Hall, 1976, p. 225. 
[24]Jeyamalar Kathirithamby-Wells, "Restraints on the Development of Merchant Capitalism in Southeast Asia before c. 1800", In Southeast Asia in the Early Modern Era, (eds.) Anthony Reid, Cornell University Press, Ithaca, 1993, p. 127; William Foster, (eds.), A New Account of the East Indies -by Alexander Hamilton, Vol I-II, N. Israel/Amsterdam, 1970, p. 60; Ito Takeshi, 1984, p. 275; Anthony Reid, "Introduction”, 1993, p. 8.

[25]J. Paulus, Asal Usul Raja-Raja Aceh, (eds.), Encyclopedie van N.I. 1917 (H. 72-76) A-G, p. 27-8; H. M. Zainuddin, Tarich Atjeh dan Nusantara, Pustaka Iskandar Muda, $1^{\text {st }}$ edition, Medan, 1961, p. 272; Jeyamalar Kathirithamby-Wells, 1993, p. 144.

[26]Jeyamalar Kathirithamby-Wells, 1993, p. 146.

[27]C.H.H. Wake, “The Changing Pattern of Europe's Pepper and Spice Imports: ca 1400-1700”, In Spices in the Indian Ocean World, (eds.) M. N. Pearson, Variorum, 1996, p. 163.

[28]Anthony Reid, 2005, p. 97.

[29]S. Arasaratnam, “Introduction”, JMBRAS, Vol. X, No. 3, December, (1969), p. 392.

[30]Razaulhak Şah, “Açi Padişahı Sultan Alaaddin'in Kanuni Sultan Süleyman'a Mektubu”, Ankara Üniversitesi DTCF, Ankara Üniversitesi Dil ve Tarih Coğrafya Fakültesi Tarih Araştırmaları Dergisi, V/8-9: 381-388; ttp://dergiler.ankara.edu.tr/dergiler/18/818/10382.pdf.

[31]F. Mendez Pinto, The Voyages and Adventures of Ferdinand Mendez Pinto: A Portugal During his Travels, tr.: Henry Cogan, An Abridged and Illustrated Edition, T. Fisher Unwin, London, 1891, p. 42; Giancarlo Casale, The Ottoman Age of Exploration, Oxford University Press, Oxford, 2010, p. 58-9; Anthony Reid, 1993, p. 164; Halil İnalc1k, 1994, p. 329.

[32]Nureddin er-Raniri, Bustan'us Salatin, (Compiled by Jelani Harun, Chapter II and III, Dewan Bahasa dan Pustaka, Kuala Lumpur, 2004, p. 338.

[33]İsmail Hakkı Uzunçarşılı, Osmanlı Tarihi, III. Cilt, I. Kısım, 3. Baskı, Türk Tarih Kurumu Basımevi, Ankara, 1983, p. 31.

[34]Giancarlo Casale, The Ottoman Age of Exploration, Oxford University Press, Oxford, 2010, p. 146.

[35]H. M. Zainuddin, 1961, p. 401.

[36]Ito Takeshi, 1984, p. 277.

[37]Peunoh Dail, Hukum Perkawinan Islam, Suatu Studi Perbandingan dalam Kalangan AhlusSunnah dan Negara-Negara Islam, (A Comparative Study in Ahlus-Sunnah and Islamic Countries), Bulan Bintang, Publisher and Distributor of Jakarta's books, Indonesia, 1988, p. 13. 
[38]Ali Hasjmy, "Banda Aceh Darussalam Pusat Kegiatan Ilmu Dan Kebudayaan", Aceh Timur 25-30 September, 1980, p. 5; Metin Kunt, "The Later Muslim Empires: Ottomans, Safavids, Mughals", Marjorie Kelly (Ed.), Islam: The Religious and Political Life of a World Community, Praeger, New York, 1984, s. 117; A. K. Jakobi, Aceh Dalam Perang Mempertahankan Proklamasi Kemerdekaan 1945-1949 Dan Peranan Teuku Hamid Azwar Sebagai Pejuang, PT. Gramedia Pustaka Utama, Foundation of Seulawah, Cakarta, 2004, p. 17; Anthony Reid, 1995, p. 54; Ali Hasjmy, "Bagaimana Agar Peranan Pemimpin-pemimpin Agama benar-benar Menjadi Kenyataan", SINAR DARUSSALAM, p. 8.

[39]Before and during the Dutch War, there were around 60 news items of various dates pertaining to this war, drumming up support for the Acehnese, in a journal entitled Basiret published in Istanbul. More manuscripts regarding the Dutch War can be found in the Ottoman Archive in Istanbul See: HR.SYS.551/2; HRS.SYS 551/5 (39); HR.SYS 551/5 (45)b.

[40]Anthony Reid, 2010, p.120. 